\title{
JFTH
}

Vol. 18, Issue 1 (2021)

ISSN: 2314-7024

E-ISSN: 2682-2180

\section{Safety of Foods Served in the Local Fast-Food Restaurants in Alexandria (Egypt): Customers Observation versus Laboratory Examination}

\section{Hazem Ahmed Khairy}

Associate Professor, Hotel Studies Department

Faculty of Tourism and Hotels, University of Sadat City, Egypt

\section{Shimaa Abo Elsoad Mohamed Soliman}

Lecturer - Hotel Studies Department

The Higher Institute for Tourism, Hotels and Computer Sciences, Seyouf, Alexandria, Egypt

\section{Mohamed Ahmed Khairy}

Veterinarian, Menoufia University, Egypt

\begin{abstract}
Today, contamination of food by microbial agents is a worldwide concern. This study aimed to examine the presence of Shiga toxinproducing E. coli (STEC) bacteria in foods served in the local fast-food restaurants in Alexandria (Egypt), investigate food safety handling practices in the local fast-food restaurants, besides, assess customer's awareness of the prerequisites of safe food at local fast-food restaurants. This study was based on two different methodologies; namely, survey methodology and laboratory examination methodology.
\end{abstract}

Data for laboratory examination were collected from (90) food samples collected from (11) local fast-food restaurants within three tourist shopping malls located in Alexandria city in Egypt. Also, data from (387) customers were analyzed. The results of the microbiological examination revealed that one-third of collected food samples contain the Shiga toxin-producing E. coli. The findings of the study also revealed a shortage in the application of personal hygiene standards in the local fast-food restaurants; besides, the customers do not have sufficient awareness of the prerequisites of food safety at local fast-food restaurants. This study deepens the understanding of the concept of food safety in local fast-food restaurants, consequently, could help ensure food safety and protect the tourists' health.

\section{Keywords}

Food Safety, Shiga Toxin-producing E. coli, Laboratory Examination, Customers' Awareness, Local Fast-food Restaurants.

\section{Introduction}

It's no doubt that fast-food has become a part of our society and our daily life due to some reasons such as changes in our lifestyle, low cost, and the enormous fast-food restaurant's 
advertisements. The phenomenon of fast-food is increasing rapidly; almost no street does not involve at least one of the fast-food restaurants. The concept of fast-food is associated with hundreds of years ago. For starting any fast-food business, the capital requirements are relatively lower than any other business, that is the reason for all over the world individually owned fast-food restaurants are increasing (Khan et al., 2013). In 2017, the hotel and restaurant sector in Egypt grew by 33 percent, and this due to recovering tourism and normalization of spending patterns among Egyptians. It is forecasted to continue to increase demand and growth to reach 15-20 percent by 2021 as tourism and consumer purchasing power continues to recover (El-Habbal and Abdi, 2018).

However, fast-food has dangerous and negative impacts on our health (Al-Saad, 2016). Food safety is an important matter linked to food preparation, distribution, and consumption to avoid food contamination and ensuring quality (Prabhakar et al., 2010). In general, food safety is a public health priority because millions of persons get ill as a result of eating unsafe food (World Health Organization, 2009). Food has a great impact on tourists' health and influences tourists' destination selection process (Bonn et al., 2005). Today's tourists have the desire to pay much more to eat foods with a higher safety level (Laesser and Peters, 2005). Destinations with poor health and safety reputations may be less attractive to many travelers (Choi et al., 2013).Unfortunately, developing, countries including Egypt, are probably more at risk of foodborne illness due to the limited disease surveillance and prevention and control strategies they have (Todd, 2017).

Escherichia coli (E. coli) is one of the most frequent causes of many common bacterial infections including cholecystitis, urinary tract infection, and traveler's diarrhea (Shah et al., 2009). Recent studies have shown that about $25 \%$ of travelers suffered from traveler's diarrhea in the first two weeks out of the country, with the highest rates happening in a trip to Africa and South, Central, and West Asia (Pitzurra et al., 2010). As for Egypt, some travelers who visited Hurghada experienced foodborne illness caused by an E. coli infection (TravelHealthPro, 2019). E. coli occurrence has caused a wave of fear across Europe after killing at least 22 people. The bacteria results in severe bleeding in the intestines and is considered to be terminal. Contamination by food handlers is the main reason for approximately 10 to $20 \%$ of foodborne disease outbreaks (Abdelrazig et al., 2017).

Although fast-food restaurants in Egyptian shopping malls are subject to local inspections by public health departments, still a relatively high percentage of restaurants have inadequate food hygiene practices. Moreover, the prevention of foodborne illnesses needs increasing awareness among customers on safe food handling practices. This food safety awareness would assist consumers who are in danger to identify ways of preventing healththreatening food safety troubles.

Therefore, the current study aimed to examine the presence of Shiga toxin E. coli (STEC) bacteria in foods served in the local fast-food restaurants in tourist shopping malls in Egypt, investigate food safety handling practices in the local fast-food restaurants in shopping malls, besides, assess customers' awareness of food safety and hygiene in local fast-food. Consequently, understanding the threats associated with consuming foods contaminated with Shiga toxin E. coli in local fast-food restaurants could help ensure food safety and protect the tourist's health. Ultimately, this study may bridge the gap that 
exists in the literature particularly on the local fast-food restaurants.

\section{Theoretical Foundation and Hypotheses Development}

\subsection{Fast-food restaurants in Egypt: An overview}

The Egyptian fast-food market has a remarkable expansion since it started in 1970. The increase is anticipated to continue at an annual rate of $20-25$ percent during the next years. The size of the food franchise market is more than USD 750 million. In 1993 there were seven chains have been operated in Egypt, now there are over 50 American franchises that are opened or have coming up with tactics to open. Additionally, many American franchisors continue to enter the Egyptian market (U.S. Commercial Service and the Department of State, 2010).

Abdelgawwad (2019) reported that the largest part of foreign and local franchises are started in Cairo. International franchises were opening in Egypt as McDonald's, KFC, Pizza Hut, Hardee's, Burger King QSRs, etc. Abdelgawwad (2012) stated that there are local fast-food restaurants like Mo'men, Cook Door, Wessaya, Gad, Felfela, ElShabrawy QSRS, and others. Moreover, recently numerous local Egyptian quick-service restaurant chains are serving fast meals and sandwiches like Chicken Pane, Fried spicy liver sandwiches, Kebab Shish Tawook, Kofta, Shawarma, Foul, Falafel, and Koshary to suit Egyptian preferences taste. He also stated that the quick service restaurants industry in Egypt involved 24\% international franchises and $76 \%$ local franchisees, $40 \%$ of international franchisees are American chains. US franchisees are about $35 \%$ of total franchise revenues in Egypt .

\subsection{Fast-food restaurants: Concept and Segments}

Fast-food has also been defined as a "convenience food" or food bought in selfservice without waiter service (Rosenheck, 2008). Fast-food is described as food with low-time preparation and served packaged to clients (Khan et al., 2013). Pingali and Khwaja (2004) pronounced that fast-food is an up-and-coming trend whereby it is trickling down from the restaurant to street level, where fast-food is sold as street food. Davidson (2014) distinguished fast-food as a phenomenon characterized by the idea of going into a public eating space and requesting food items that will come rapidly and can be eaten speedily. Selvarajn (2012) added that ready-to-eat food is a foodstuff offered for sale without extra cooking or preparation, which is packaged on the property where they are sold and are ready for eating. Ready-to-eat foods include canned foods, convenience foods, fast foods, frozen foods, instant products, dried foods, preserved foods, etcr.

Andrews (2013) defined fast-food restaurants as restaurants that provide ready-to-eat food in minutes after its order, and it has certain main features; each food and beverage item is individually priced, food is normally dry finger foods, it is a tray service, besides, the menu items depicted through colorful transparencies behind the cashier. Egypt Business Directory (2016) argued that at quick-service restaurants, foodstuff is catering in a short period through self-service or table service. Burgers, sandwiches, and chicken products are the basic items served in fastfood restaurants. The fast-food market is segmented based on product types such as burgers, sandwiches, hotdogs, Italian (pizza/pasta, etc.), Asian, Mexican, and Latin 
American and others and kinds of a restaurant as chained quick-service restaurants and unchained restaurant. Al-Saad (2016) reminded of items served in fast-food restaurants, which are chicken nuggets, burgers and fried potato cutter, canned chips, pies, pizza, and soft drinks, it calls fast-food because it is simple to prepare and eat. Andrews (2008) presented the concept of fast- food now based on each country has perfected its specialty food like Indian, Samosa Idli, and Wada; Lebanese shawarma, however, the hamburger is the king.

\subsection{Escherichia Coli Bacteria: Infection, Symptoms, and Causes}

E. coli is the most important foodborne pathogenic bacteria. E. coli is a major component of the normal intestinal flora of humans and other mammals which are usually harmless to the host and only cause diseases in immune-compromised hosts or when the gastrointestinal barriers are breached. However, some specific E. coli strains "i.e. Shiga toxin-producing E. coli (STEC) that can cause severe foodborne disease" represent primary pathogens with the enhanced potential to cause disease after acquiring specific virulence attributes (Li et al., 2005). Golan et al., (2004) wrote that the beginning of E. coli infection at restaurants is local; there are a lot of examples of local and national E. coli infections. Winstead et al., (2019) refereed to The WHO Global Burden of foodborne diseases report that estimates more than 300 million illnesses and nearly 200,000 deaths are caused by E. coli globally each year. U.S. Food \&Drug Administration (2019) declared that E. coli can live inside human and some E. coli species do not source of diseases, but, there are other kinds of $E$. coli are a reason in dangerous illness. E. coli can come into the body through contaminated food or water, and is often contribute to major the spread of foodborne disease around the globe. Some reports indicated that around ten percent of the travel population is affected by food-borne illness every year (MacLaurin et al., 2000), and approximately thirty percent of visitors to Asia, Latin America, and Africa suffered food-borne illness such as diarrhea (Yeung, 2009).

The World Health Organization (WHO, 2000) declared that ready-to-eat foods like meat pie, burgers, coleslaw, fried chicken, milk, and milk products should ensure their safety from contaminants and microorganisms. Many foods are repeatedly contaminated with occurring pathogenic microorganisms that cannot be detected organoleptically but are a reason for diseases including death especially if the preserving method during the offering for the sale provides the circumstance for those microorganisms to grow and reach considerable levels of contamination. As discussed earlier, E. coli bacteria can easily be transmitted from one person to another person. E. coli outbreaks have also occurred in local fast-food restaurants; accordingly, the following hypothesis is formulated:

Hypothesis one: There is possibility of the presence of Shiga toxin-producing E. coli bacteria in meals served in local fast-food restaurants.

\subsection{Food safety awareness and food handling practices}

Musa and Akande (2002) explained that people consume a large amount of ready-toeat fast-food because of a transform in social behaviors, which is distinguished by increased movement, large numbers of itinerary employees, and less family-centered activities. Thus, good manufacturing practices of foods taken outside the home such as good 
sanitation or sanitary measure and proper food handling has been transferred from individuals or families to the food vendor who rarely enforces such practice. Mosupye and Van Holy (2000) ensured that infrequently, food handling employees may transmit pathogens that they are conveyed in or on their bodies to food, and such pathogens may stay alive and grow in the foodstuff and consequently cause disease.

Inappropriate food preparation practices can be a reason for foodborne illness as referred by Park et al. (2010). Kiranmayi et al. (2010) stated that the majority of transmission is through the eating of undercooked contaminated ground meat consumption of raw milk, raw vegetables, fruits contaminated by unclean water, cheese, curd, and also through consumption of sprouts, lettuce, and juice, hence the prevalence and occurrence of E. coli. The European Parliament and The Council of The European Union (2004) confirmed that local authorities and inspection services are responsible for inspecting restaurants to ensure that hygiene requirements are met, delivering safe food to consumers is followed by operators at all levels of the food production chain. Food can be handled improperly way during food preparation, handling, and storage. Numerous studies showed that consumers have inadequate knowledge of procedures required to avoid foodborne illnesses (Mederios et al., 2001).

Restaurants can keep away from the sickness from $E$. coli by committed to safe food handling, cooking meats carefully, and avoiding using unpasteurized juices and milk, which in turn, could prevent food spoilage that causes a pathogenic effect on individuals (Winstead et al., 2019). Based on the previous studies which demonstrate that the occurrence of E. coli is linked with poor personnel hygiene practices, the following hypothesis is formulated:

\section{Hypothesis two: There is a shortage in the} application of personal hygiene standards in the local fast-food restaurants.

According to Ellis et al., (2003), consumer behaviors and attitudes to safe food should be taken into account in food safety educational programs and material developments to wholly describe the word "food safety" and to define the incorrect actions and beliefs of the customers. Also, it is so important to instruct consumers (Wilcock et al., 2004). According to Surujlal and Badrie (2004), consumers' behaviors at their homes reflect their knowledge or at least what they believe about food safety. The prevention of foodborne illnesses needs learning consumers about safe food handling practices (Jevšnik et al., 2008). National and international surveys showed that individuals still do not have proper information about food safety (Haapala \&Probart, 2004); accordingly, the following hypothesis is formulated:

\section{Hypothesis three: The customers do not have sufficient awareness of the prerequisites of safe food at local fast-food restaurants.}

Several tips need to be taken into an account such as personal hygiene from the tip of the hair to the tip of the foot. This has an outcome because healthy food employees will prepare quality food (Auliya et al., 2016), and hence, prevent tourism revenues from being interrupted (World Travel and Tourism Council, 2007).

\section{Methodology}

\subsection{Laboratory Examination}

Firstly, the practical part of this study was based on laboratory examination methodology. The data were collected from 
local fast-food restaurants inside three tourist shopping malls. A random sample of (11) local fast-food restaurants located in Alexandria city in Egypt was chosen for investigation. Six food items namely; Beef burger, Beef sausage, Beef Shawerma, Chicken Pane, Chicken Shawarma, and Chicken Fahita were chosen for examination. Such meat and meat products food items are classified as potentially hazardous foods and they are considered as a good media for many pathogenic organisms to grow because of their high moisture contents, rich in nitrogenous compounds (amino acids, peptides, proteins) furthermore, they have some fermentable carbohydrates usually glycogen and keep favorable $\mathrm{pH}$ for growth of microorganisms (Galvez et al., 2010).

A total number of (90) food items "(15) samples for each food item" was collected for the laboratory test. For Beef burger samples, five samples were collected from each of Local Fast Food Restaurant (LFFR) 1, LFFR 4, and LFFR 5. For Beef sausage samples, five samples were collected from each of LFFR 2, LFFR 7, and LFFR 11. For Beef Shawerma samples, five samples were collected from each of LFFR 3, LFFR 7, and LFFR 11. For Chicken Pane samples, five samples were collected from each of LFFR 6, LFFR 8, and LFFR 9. For Chicken Shawarma samples, five samples were collected from each of LFFR 3, LFFR 7, and LFFR 10. For Chicken Fahita samples, five samples were collected from each of LFFR 7, LFFR 9, and LFFR 10.

Samples were transferred to the laboratory "Animal Health Research Institute, Shebin ElKoum" in plastic jars and metal containers. Containers used were clean, dry, leak-proof, wide-mouth, sterile, and of a size suitable for samples of products. Samples were delivered to the laboratory promptly. Samples were transported in a sample chest with a suitable refrigerant capable of maintaining the sample at $0-4 \mathrm{C}$ until arrival at the laboratory.

\subsection{Survey Methodology}

This study was based on the survey method. Google Doc Forms is used to create an online survey. The survey form consisted of four parts. The first part collected information on demographic factors for the characteristics of the customers such as gender, age, and education. In the second part, respondents firstly asked to assure that they are previously bought food from the local fast-food restaurants in Alexandria governorate in Egypt before, their preferences toward foods served in the local fast-food restaurants, and foodborne disease symptoms they experienced after eating foods from the local fast-food restaurants. The third part collected customers' observations towards food safety and hygiene practices in the local fast-food restaurants. This part contains twelve statements and customers were asked to describe their answer on the five Likert scales from" never" to "very often". In the fourth part, respondents were also asked about their knowledge of food safety on a dichotomous scale from "Yes", "No".

A total of 387 respondents have submitted their answers. Data analysis was then performed using the Statistical Package for the Social Sciences (SPSS v. 23). To describe and summarize the data, descriptive statistics (i.e., means and standard deviations) were applied.

\section{Results}

\subsection{Laboratory Test Analysis results}

Table (1) and figure (1) show the results of the microbiological examination that was done to detect the presence of E-coli in foods served in the local fast-food restaurants. Out of 90 food samples, $33.33 \%(n=30)$ contain E. coli whereas $66.66 \%(\mathrm{n}=60)$ do not contain E. coli. The number of positive food samples was $20 \%(n=3), 33.33 \%(n=5)$, $33.33 \%(n=5), 26.66 \%(n=4), 40 \%(n=6)$, 
and $46.66 \%(n=7)$ for Beef burger, Beef sausage, Beef Shawerma, Chicken Pane,
Chicken Shawarma, and Chicken Fahita; respectively

\section{Table (1): Results of the Laboratory Test Analysis}

\begin{tabular}{|c|c|c|c|c|c|c|c|}
\hline \multirow{2}{*}{ Sandwiches } & \multirow{2}{*}{ Samples } & \multicolumn{2}{|c|}{ Positive Samples } & \multicolumn{2}{|c|}{ Negative Sample } & \multicolumn{2}{|c|}{ Positive Samples } \\
\hline & & No & $\%$ & No & $\%$ & Mean & SD \\
\hline Beef burger & 15 & 3 & 20 & 12 & 80 & .20 & .41 \\
\hline Beef sausage & 15 & 5 & 33.33 & 10 & 66.66 & .33 & .48 \\
\hline $\begin{array}{c}\text { Beef } \\
\text { Shawerma }\end{array}$ & 15 & 5 & 33.33 & 10 & 66.66 & .33 & .49 \\
\hline $\begin{array}{c}\text { Chicken } \\
\text { Pane }\end{array}$ & 15 & 4 & 26.66 & 11 & 73.33 & .27 & .45 \\
\hline $\begin{array}{c}\text { Chicken } \\
\text { Shawarma }\end{array}$ & 15 & 6 & 40 & 9 & 60 & .40 & .51 \\
\hline $\begin{array}{c}\text { Chicken } \\
\text { Fahita } \\
\end{array}$ & 15 & 7 & 46.66 & 8 & 53.33 & .47 & .52 \\
\hline $\begin{array}{c}\text { Total } \\
\text { Samples }\end{array}$ & 90 & 30 & 33.33 & 60 & 66.66 & .33 & .47 \\
\hline
\end{tabular}

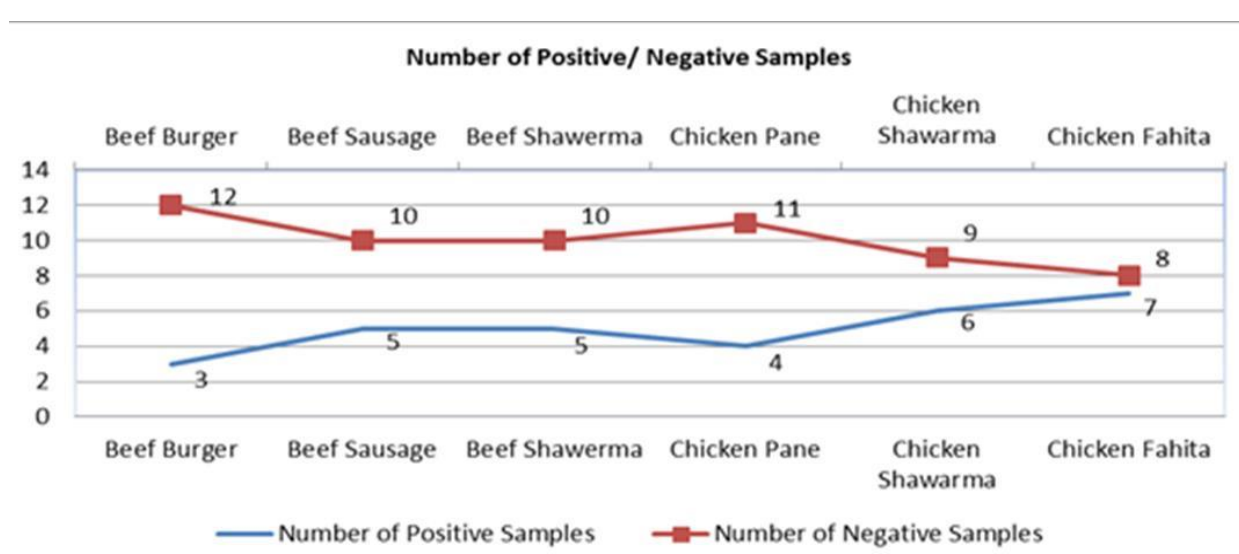

Table (1) also shows that the mean value of positive samples in each of the investigated items was .20 $(\mathrm{SD}=.41), .33(\mathrm{SD}=.48), .33$ $(\mathrm{SD}=.49), .27 \quad(\mathrm{SD}=.45), .40 \quad(\mathrm{SD}=.51)$, and $.47(\mathrm{SD}=.52)$ for a Beef burger, Beef sausage, Beef Shawerma, Chicken Pane, Chicken Shawarma, and Chicken Fahita; respectively

\subsection{Survey results}

According to results in table (2), nearly half $49.6 \%(\mathrm{n}=192)$ of respondents were male, and 50.4\% ( $\mathrm{n}=195)$ were female. The majority of the participants were 17-30 years old $83.2 \%(n=322)$. More than two-thirds of respondents had a bachelor's degree $79.3 \%(n=307)$.
Table (2): Respondents' profile

\begin{tabular}{|l|c|c|}
\hline & Number & Percent \\
\hline Gender & & \\
\hline Male & 192 & 49.6 \\
\hline Female & 195 & 50.4 \\
\hline Age & & \\
\hline$<17$ & 1 & .3 \\
\hline $17-30$ & 322 & 83.2 \\
\hline $31-50$ & 59 & 15.2 \\
\hline$>50$ & 5 & 1.3 \\
\hline Education & & \\
\hline High school & 9 & 2.3 \\
\hline Bachelor degree & 307 & 79.3 \\
\hline Master/doctorate degree & 71 & 18.3 \\
\hline
\end{tabular}

Besides, results in a table (3) presented customers' preferences towards food items 
served in the local fast-food restaurants. The most preferred food items were $52.20 \%$ $(n=202)$ for Chicken Shawarma , 31.5\% $(n=$ 122) for Beef burger, 29.97\% $(n=116)$ for Chicken Pane, 22.74\% $(n=88)$ for Beef Shawerma, 21.71\% $(n=84)$ for Chicken Fahita, and $12.67 \%$ (49) for Beef sausage. However, Seafood and Spicy Shrimp were the least preferred items (11.89\% and $8.79 \%$, respectively).

Table 3 Customer's preferences toward food items served in the local fast-food restaurants.

\begin{tabular}{|l|c|c|}
\hline & No. & \% \\
\hline $\begin{array}{l}\text { Items customers prefer to eat at } \\
\text { the local fast-food restaurants }\end{array}$ & & \\
\hline Beef Burger Sandwich & 122 & 31.5 \\
\hline Chicken Pane Sandwich & 116 & 29.97 \\
\hline Beef Shawerma Sandwich & 88 & 22.74 \\
\hline Chicken Shawerma Sandwich & 202 & 52.20 \\
\hline Chicken Fahita Sandwich & 84 & 21.71 \\
\hline Beef sausage Sandwich & 49 & 12.67 \\
\hline Seafood Sandwich & 46 & 11.89 \\
\hline Spicy Shrimp Sandwich & 34 & 8.79 \\
\hline Note: One respondent may select more than one food item. \\
\hline
\end{tabular}

Furthermore, data in the table (4) illustrated that approximately one-third of the respondents experienced food poisoning $(n=$ 86), half of the respondents caught diarrhea $(n=194)$, and $65.9 \%(n=255)$ suffered colic due to eating fast-food meals.
Table 4 Foodborne disease symptoms as experienced by respondents.

\begin{tabular}{|c|c|c|}
\hline Statements & No. & $\%$ \\
\hline \multicolumn{3}{|c|}{$\begin{array}{l}\text { Have you infected a food poisoning due to food } \\
\text { consumed from local fast-food restaurants before? }\end{array}$} \\
\hline Yes & 86 & 22.2 \\
\hline No & 301 & 77.8 \\
\hline \multicolumn{3}{|c|}{$\begin{array}{l}\text { Have you experienced diarrhea due to food } \\
\text { consumed from local fast-food restaurants before? }\end{array}$} \\
\hline Yes & 194 & 50.1 \\
\hline No & 193 & 49.9 \\
\hline \multicolumn{3}{|c|}{$\begin{array}{l}\text { Have you ever had colic from food previously } \\
\text { consumed by local fast-food restaurants? }\end{array}$} \\
\hline Yes & 255 & 65.9 \\
\hline No & 132 & 34.1 \\
\hline
\end{tabular}

According to table (5), the mean score of customers' observations about the cleanliness of restaurants was $3.68(\mathrm{SD}=.85)$, the mean score of customers' observations about restaurants staff was $3.16(\mathrm{SD}=.84)$ and was $3.42(\mathrm{SD}=.78)$ for customers' overall observations toward food safety and hygiene in the local fast-food restaurants. Regarding the cleanliness of the restaurant, a total of, $33.1 \%$ of the sample observed very often cleanliness of serving utensils, however, only $20.7 \%$ of the respondents reported that they observed very often cleanliness of cutlery, dishes, etc. On the other hand, respondents that observed that staff avoid touching their face over or near food very often were $24.3 \%$, but only $11.4 \%$ of respondents observed that all Restaurant staff use gloves in handling food.

Table (5) Customers' observation towards food safety and hygiene practices in the local fast-food restaurants

\begin{tabular}{|c|c|c|c|c|c|c|c|c|c|c|c|c|}
\hline & & & \multicolumn{2}{|c|}{ Never } & \multicolumn{2}{|c|}{ Rarely } & \multicolumn{2}{|c|}{ Sometimes } & \multicolumn{2}{|c|}{ Often } & \multicolumn{2}{|c|}{ Very often } \\
\hline Statements & Mean & $\mathrm{SD}$ & $\mathrm{N}$ & $\%$ & $\mathrm{~N}$ & $\%$ & $\mathrm{~N}$ & $\%$ & $\mathrm{~N}$ & $\%$ & $\mathrm{~N}$ & $\%$ \\
\hline \multicolumn{13}{|c|}{ Customers' observations about the cleanliness of the restaurant } \\
\hline $\begin{array}{l}\text { Cleanliness of tables and } \\
\text { chairs }\end{array}$ & 3.60 & 1.031 & 19 & 4.9 & 17 & 4.4 & 147 & 38.0 & 119 & 30.7 & 85 & 22.0 \\
\hline $\begin{array}{c}\text { Cleanliness of floor, roof, } \\
\text { wall }\end{array}$ & 3.60 & 1.057 & 15 & 3.9 & 34 & 8.8 & 133 & 34.4 & 115 & 29.7 & 90 & 23.3 \\
\hline $\begin{array}{c}\text { The restaurant area is free of } \\
\text { insects, rats, etc. }\end{array}$ & 3.77 & 1.183 & 26 & 6.7 & 31 & 8.0 & 75 & 19.4 & 128 & 33.1 & 127 & 32.8 \\
\hline $\begin{array}{c}\text { Cleanliness of cutlery, dishes, } \\
\text { etc. }\end{array}$ & 3.83 & 1.147 & 25 & 6.5 & 22 & 5.7 & 77 & 19.9 & 134 & 34.6 & 129 & 33.3 \\
\hline Cleanliness of bathrooms & 3.46 & 1.134 & 22 & 5.7 & 54 & 14.0 & 115 & 29.7 & 116 & 30.0 & 80 & 20.7 \\
\hline Cleanliness of serving utensil & 3.84 & 1.085 & 16 & 4.1 & 25 & 6.5 & 92 & 23.8 & 126 & 32.6 & 128 & 33.1 \\
\hline \multicolumn{13}{|c|}{ Customers' observations about restaurant staff } \\
\hline $\begin{array}{l}\text { Staff can avoid direct contact } \\
\text { in handling food. }\end{array}$ & 3.13 & 1.171 & 35 & 9.0 & 84 & 21.7 & 115 & 29.7 & 100 & 25.8 & 53 & 13.7 \\
\hline $\begin{array}{l}\text { All Restaurant staff use } \\
\text { gloves in handling food. }\end{array}$ & 2.93 & 1.191 & 48 & 12.4 & 101 & 26.1 & 113 & 29.2 & 81 & 20.9 & 44 & 11.4 \\
\hline
\end{tabular}




\begin{tabular}{|c|c|c|c|c|c|c|c|c|c|c|c|c|}
\hline $\begin{array}{l}\text { All Restaurant staff wears a } \\
\text { clean uniform when handling } \\
\text { food. }\end{array}$ & 3.55 & 1.098 & 16 & 4.1 & 50 & 12.9 & 112 & 28.9 & 122 & 31.5 & 87 & 22.5 \\
\hline $\begin{array}{l}\text { Staff don't wear watches or } \\
\text { jewelry when preparing food }\end{array}$ & 2.93 & 1.253 & 57 & 14.7 & 92 & 23.8 & 112 & 28.9 & 72 & 18.6 & 54 & 14.0 \\
\hline $\begin{array}{l}\text { Staff have clean hair and wear } \\
\text { a suitable head covering }\end{array}$ & 3.03 & 1.157 & 30 & 7.8 & 112 & 28.9 & 110 & 28.4 & 85 & 22.0 & 50 & 12.9 \\
\hline $\begin{array}{l}\text { Staff avoid touching their } \\
\text { face over or near food }\end{array}$ & 3.40 & 1.245 & 29 & 7.5 & 72 & 18.6 & 96 & 24.8 & 96 & 24.8 & 94 & 24.3 \\
\hline \multicolumn{13}{|c|}{$\begin{array}{c}\text { Customers' observations about Cleanliness of restaurant } \\
\text { Mean: } 3.68 \\
\text { Std. Deviation: } .85 \\
\text { Customers' observations about restaurant staff } \\
\text { Mean: } 3.16 \\
\text { Std. Deviation: } .84 \\
\text { Mean: } 3.42 \\
\text { Sustomers' overall observations of food safety and hygiene } \\
\text { Std. Deviation: } .78\end{array}$} \\
\hline
\end{tabular}

The figures and percentages in the table (6) showed the respondents' knowledge of food safety. The results found that respondents had a better general knowledge of food safety than In-depth knowledge. Regarding general knowledge about food safety, respondents answered correctly to wash hands with soap before cooking with $94.6 \%$ of respondents, and after touching meat with $88.9 \%$ of respondents, followed by maintaining raw meats away from other foods with $88.4 \%$ of respondents. Inadequately cooked meat causes illnesses were answered correctly with $70.5 \%$ of respondents, however, $50.1 \%$ of the sample who answered correctly to raw eggs might be a reason for illnesses and only $46.3 \%$ of respondents answered correctly too if one has diarrhea, can prepare food for others if one washes hands or not.

Table (6): Customers' knowledge of food hygiene and safety

\begin{tabular}{|c|c|c|c|c|c|}
\hline \multirow[t]{2}{*}{ Statements } & \multicolumn{2}{|c|}{$\begin{array}{l}\text { Correct } \\
\text { Answer }\end{array}$} & \multirow{2}{*}{$\begin{array}{c}\begin{array}{c}\text { Incorrect } \\
\text { Answer }\end{array} \\
\text { No } \\
\end{array}$} & \multicolumn{2}{|c|}{$\begin{array}{c}\text { Correct } \\
\text { answer Index }\end{array}$} \\
\hline & No & $\%$ & & $\%$ & \\
\hline \multicolumn{6}{|l|}{ General knowledge about food safety } \\
\hline 1- One should wash hands with soap before cooking & 366 & 94.6 & 21 & 5.4 & Yes \\
\hline $\begin{array}{l}\text { 2- If one has diarrhea, it is okay to prepare food for others if one washes } \\
\text { hands. }\end{array}$ & 179 & 46.3 & 208 & 53.7 & No \\
\hline 3-Food made with raw eggs might be a reason for illnesses. & 194 & 50.1 & 202 & 49.8 & Yes \\
\hline 4- Inadequately cooked meat causes illnesses. & 273 & 70.5 & 114 & 29.5 & Yes \\
\hline 5-One should maintain raw meats away from other foods. & 342 & 88.4 & 45 & 11.6 & Yes \\
\hline $\begin{array}{l}\text { 6-After touching meat, one should wash hands with soap before } \\
\text { preparing another meal }\end{array}$ & 344 & 88.9 & 43 & 11.1 & Yes \\
\hline \multicolumn{6}{|l|}{ In-depth knowledge about food safety } \\
\hline $\begin{array}{l}\text { 7-Beef Meat and poultry are the most exposed foods to be contaminated } \\
\text { with E. coli bacteria. }\end{array}$ & 187 & 48.3 & 200 & 51.7 & Yes \\
\hline 8-One can't prepare food if he has diarrhea. & 171 & 44.2 & 216 & 55.8 & Yes \\
\hline 9-E. coli bacteria can cause human diseases if they are found in food. & 96 & 24.8 & 291 & 75.2 & Yes \\
\hline 10-E.Coli bacteria can be spread easily from person to person. & 118 & 30.5 & 269 & 69.5 & Yes \\
\hline $\begin{array}{l}\text { 11-E.Coli bacteria can be spread from someone's face or mouth to their } \\
\text { hands and then onto food. }\end{array}$ & 114 & 29.5 & 273 & 70.5 & Yes \\
\hline 12-Clothes can bring bacteria into food handling areas & 282 & 72.9 & 105 & 27.2 & Yes \\
\hline
\end{tabular}

The figures and percentages in the table (6) knowledge, customers had a reasonable also showed that, regarding general amount of information but a few of them need 
to enhance basic information related to the general knowledge of food safety. About $72.9 \%$ of participants had awareness of clothes can bring bacteria into food handling areas, but only $24.8 \%$ of respondents were aware of E. coli bacteria can cause human diseases if they are found in food.

\section{Discussion and Implications}

Due to the burden of foodborne illnesses on public health, ensuring food safety is highly important. Therefore, this study aimed to examine the presence of Shiga toxin E. coli (STEC) bacteria in foods served in the local fast-food restaurants, investigate the application of personal hygiene standards and food safety practices in the local fast-food restaurants in shopping malls in Alexandria Egypt, in addition to assessing customers' awareness of the prerequisites of safe food at local fast-food restaurants.

The results showed that the first hypothesis of the study was supported. Shiga toxin E. coli (STEC) bacteria already exist as evidenced by the laboratory analysis- in foods served in the local fast-food restaurants (see table 1 \& figure 1). This is due to the lack of personal hygiene of the food handlers and the failure to follow the necessary precautions when preparing food in the local fast-food restaurants. This result is interpreted by Cohen et al. (2007), meals that contain meats are especially a common source of $E$. coli contamination, which may be acquired during slaughter through fecal contact. Moreover, the results also showed an increased number of positive samples in poultry products than beef meat products. This is because the bacterial contamination of poultry meat depends on the intestine content which may come in contact with carcasses already in the broiler house and during transport and slaughter through transport and processing equipment. Ray (2004) and Yashoda et al.
(2001) stated that contamination levels may also increase during the evisceration of the carcasses, washing, and processing due to contamination by personnel. The presence of pathogenic strains of $E$. coli in poultry and beef meat products such as Chicken Fahita, Chicken Shawarma, and Beef Shawerma is the most potent threat of cross-contamination, and also can become an infectious source for handlers and consumers.

The results of the laboratory examination were in the line with information obtained from the customers included in this study (see table 4). Customers suffered from food poisoning, diarrhea, and colic when consumed foods served at local fast-food restaurants. These symptoms were a result of $E$. coli bacteria infection as confirmed by Ray (2004) who ensures that Pathogenic E. coli strains are responsible for enteric and diarrheal diseases, urinary tract infections, and sepsis and meningitis.

The study also revealed that the second hypothesis proposed by the current study was supported (see Table 5). There was a shortage in the application of personal hygiene standards in the local fast-food restaurants as observed by customers. It might be difficult to ignore the fact that service providers in the local fast-food restaurants pay more attention to clean serving cutlery, utensils, and walls than to cleanliness of the bathrooms. This result is interpreted by Rigby (2019) who claimed the $E$. coli bacteria is more likely to be spread through poor toilet hygiene than through undercooked meat or other food. Furthermore, fast-food operators don't give enough interest to personal hygiene for food handlers like using gloves in handling food, having clean hair, and wearing a suitable head covering, and avoiding direct contact with food. All of these practices reflect a lack of implementation of personal hygiene practices in local fast-food restaurants, and hence, a 
shortage in food safety and hygiene practices and how to prevent foodborne illnesses and $E$. coli infection from food. This is consistent with what is reported by Ellis and Goodacre (2001) and Knowles et al. (2007) that the presence of $E$. coli is a fecal pollution indicator in chefs' and food handlers' hands.

Additionally, the findings of the study also support the third hypothesis proposed that customers do not have sufficient awareness of the prerequisites of safe food at local fast-food restaurants (table 6). Results revealed that customers do not have enough knowledge about foodborne diseases, the circumstances that might lead to foodborne illness, and how food could be made safe. The results were consistent with the findings of Albin (2015) who argued that customers don't have an understanding of what behaviors lead to risk, so safe food handling knowledge is needed as stated by Fawzi and Sharma (2009). Importantly, figures of local foodborne diseases tend to be increased in local fast-food restaurants that prepare and sell ready-to-eat foods as referred by El-Sherbeeny et al. (1985), particularly because the E. coli occurrence in foods is an indicator for the presence of other pathogenic bacteria in the particular food items (Shar et al., 2010).

\section{Conclusion and Recommendations}

This study relied on two different methodologies; laboratory examination and survey methods. Results of this study highlighted the presence of Shiga toxinproducing E. coli (STEC) bacteria in the food served in the local fast-food restaurants, lack of application of personal hygiene standards by food handlers, in addition to lack of customers' awareness of the prerequisites of safe food .Seriously, foodborne illnesses are a burden on public health and extremely contribute to increasing the cost of health care. Thus, investigations of bacteria that can cause severe foodborne diseases, along with analyzing behaviors that lead to food contamination, help us find where we can make improvements in food safety system spans from farm to fork.

Eventually, restaurants should adapt food handling practices to make sure good hygiene habits to prevent food-borne illnesses. Furthermore, the lack of current knowledge of food safety called for activates the role of food safety education among consumers as a strategy for preventing foodborne illnesses. Government involvement should include public service food safety education and offer incentives for engaging local fast-food restaurants to apply hygiene practices, besides the application of periodic inspection of served meal in restaurants which in turn reduce food contamination.

\section{References}

- Abdelgawwad, M. A. A. (2012). Quality management: success and failure factors for new global product development in global quick service restaurants: a case study of McDonald's Egypt (Doctoral dissertation, Cardiff Metropolitan University).

- Abdelgawwad, M. A. A. (2019). Antecedences and Consequences of Customer Purchasing Decision in the Quick Service Restaurants: Applied to Cairo. Journal of the Faculty of Tourism and Hotels- University of Sadat City, Vol. 3, Issue 2.

- Abdelrazig, A., Mustafa, K., \& Mohamed, M. (2017). Hygienic Practices among Food Handlers in Restaurants of Al-Nohod Locality Market-West Kordofan-Sudan-2017. Int J Pub Health Safe, 2(129), 2.

- Albin, M. L. (2015). Effective education on consumers' food safety knowledge, perceptions, and behaviors at local area farmers' markets.

- Al-Saad, E. (2016). Causes and effects of fast food. Biomed J Sci Tech Res, 5, 279-80.

- Andrews, S. (2008). Textbook of food and beverage management. Tata McGraw-Hill Education. 
- Andrews, S. (2013). Food and beverage service: A training manual. Tata McGraw-Hill Education.

- $\quad$ Bonn, M. A., Joseph, S. M., \& Dai, M. (2005). International versus domestic visitors: An examination of destination image perceptions. Journal of travel research, 43(3), 294-301.

- Choi, J., Lee, A., \& Ok, C. (2013). The effects of consumers' perceived risk and benefit on attitude and behavioral intention: A study of street food. Journal of Travel \& Tourism Marketing, 30(3), 222-237.

- Cohen, N., Ennaji, H., Bouchrif, B., Hassar, M., \& Karib, H. (2007). Comparative study of microbiological quality of raw poultry meat at various seasons and for different slaughtering processes in Casablanca (Morocco). Journal of Applied Poultry Research, 16(4), 502-508.

- Davidson, A. (2014). The Oxford companion to food. OUP Oxford.

- Egypt Business Directory (2016). Fast-food Market Analysis Report and Opportunities Up to 2021. Retrieved from: https://www.egyptbusiness.com/ticker/details/1650-Fast-FoodMarket-Analysis-Report-and-OpportunitiesUpto-2021/72856 .

- El-Habbal, I. and Abdi, A. (2018). Food Service Hotel Restaurant Institutional Steady Recovery for the HRI Sector in Egypt. GlOBAL agriculture information network. Available at https://apps.fas.

- Ellis, D. I., \& Goodacre, R. (2001). Rapid and quantitative detection of the microbial spoilage of muscle foods: current status and future trends. Trends in Food Science \& Technology, 12(11), 414-424.

- Ellis, J., Sebranek, J., \& Sneed, J. (2003). High school student's attitudes toward foodborne illness. In IFT Annual Meeting, IFT Annual Meeting Technical Program Abstracts 45B-5 (p. 103).

- El-Sherbeeny, M. R., Saddik, M. F., \& Bryan, F. L. (1985). Microbiological profiles of foods served by street vendors in Egypt. International Journal of Food Microbiology, 2(6), 355-364.

- Fawzi, M., \& Shama, M. E. (2009). Food safety knowledge and practices among women working in Alexandria University, Egypt. Egypt Public Health Assoc, 84(1), 9517.
- Galvez, A., Abriouel, H., Benomar, N., \& Lucas, R. (2010). Microbial antagonists to food-borne pathogens and biocontrol. Current opinion in biotechnology, 21(2), 142-148.

- Golan, E. H., Roberts, T., Salay, E., Caswell, J. A., Ollinger, M., \& Moore, D. L. (2004). Food safety innovation in the United States: evidence from the meat industry (No. 1473-2016-120703).

- Haapala, I., \& Probart, C. (2004). Food safety knowledge, perceptions, and behaviors among middle school students. Journal of nutrition education and behavior, 36(2), 71-76.

- Jevšnik, M., Hlebec, V., \& Raspor, P. (2008). Consumers' awareness of food safety from shopping to eating. Food control, 19(8), 737745.

- Khan, S., Hussain, S. M., \& Yaqoob, F. (2013). Determinants of customer satisfaction in fast food industry a study of fast food restaurants Peshawar Pakistan. Studia commercialia Bratislavensia, 6(21), 56-65.

- Kiranmayi, C., Krishnaiah, N., \& Mallika, E. N. (2010). Escherichia coli O157: H7-An Emerging Pathogen in foods of Animal Origin. Veterinary World, 3(8).

- Knowles, T., Moody, R., \& McEachern, M. G. (2007). European food scares and their impact on EU food policy. British food journal.

- Laesser, C., \& Peters, M. (2005). Does Personal Interaction Quality Really Pay? On the Influence of Personal Interaction Quality on Willingness to Pay. Tourism Analysis, 10(2), 123-135.

- Li, Y., Zhuang, S., \& Mustapha, A. (2005). Application of a multiplex PCR for the simultaneous detection of Escherichia coli O157: H7, Salmonella and Shigella in raw and ready-to-eat meat products. Meat Science, 71(2), 402-406.

- MacLaurin, T., \& LOI, S., and Maclaurin, D. (2000). Air Travelers' Attitudes to Food Safety. Conference Proceedings: Food Safety In Travel And Tourism (Vol. 17).

- Medeiros, L., Hillers, V., Kendall, P., \& Mason, A. (2001). Evaluation of food safety education for consumers. Journal of Nutrition Education, 33, S27-S34.

- Mosupye, M. and Van Holy, A. (2000). Epidemiology Hazards Identification and Exposure. South Africa. Int. J. Food Microbiology, 61 (2-3). 
- Musa, O. I., \& Akande, T. M. (2002). Effect of health education intervention on food safety practice among food vendors in Ilorin. Sahel Medical Journal, 5(3), 120.

- Park, S. H., Kwak, T. K., \& Chang, H. J. (2010). Evaluation of the food safety training for food handlers in restaurant operations. Nutrition research and practice, 4(1), 58-68.

- Pingali, P., \& Khwaja, Y. (2004). Globalisation of Indian diets and the transformation of food supply systems (No. 854-2016-56199).

- Pitzurra, R., Steffen, R., Tschopp, A., \& Mutsch, M. (2010). Diarrhoea in a large prospective cohort of European travellers to resource-limited destinations. BMC infectious diseases, 10(1), 231.

- Prabhakar, S. V. R. K., Sano, D., \& Srivastava, N. (2010). Food safety in the AsiaPacific region: Current status, policy perspectives, and a way forward. Sustainable consumption and production in the AsiaPacific region: Effective responses in a resource constrained world, 215-238.

- Ray, B. (2004). Fundamental Food Microbiology. CRC Press, Boca Raton. New York, 225-238.

- Rigby, S. (2019). More E. coli infections caused by bad toilet hygiene than undercooked meat. Retrieved from: https://www.sciencefocus.com/news/more-ecoli-infections-caused-by-bad-toilet-hygienethan-undercooked-meat/ acsessed.

- Rosenheck, R. (2008). Fast food consumption and increased caloric intake: a systematic review of a trajectory towards weight gain and obesity risk. Obesity reviews, 9(6), 535-547.

- Selvarajn, P. RM. (2012). Consumer attitudes towards Ready-To-Eat Packed food items. The Seventh international research conference on management and finance (pp. 322-332).

- Shah, N., DuPont, H. L., \& Ramsey, D. J. (2009). Global etiology of travelers' diarrhea: systematic review from 1973 to the present. The American journal of tropical medicine and hygiene, 80(4), 609-614.

- Shar, A. H., Kazi, Y. F., Kanhar, N. A., Soomro, I. H., Zia, S. M., \& Ghumro, P. B. (2010). Drinking water quality in Rohri city, Sindh, Pakistan. African Journal of Biotechnology, 9(42), 7102-7107.
- Surujlal, M., \& Badrie, N. (2004). Household consumer food safety study in Trinidad, West Indies. Internet journal of food safety, 3, 8-14.

- The European Parliament and the Council Of The European Union (2004). Regulation (Ec) No 852/2004 of the European Parliament and Of The Council. Of 29 April 2004on The Hygiene Of Foodstuffs. Official Journal Of European Union, L139, 1-54. Available from https://eur-lex.europa.eu/legalcontent/EN/TXT/?uri=celex:32004R0852.

- Todd, E. C. (2017). Foodborne Disease in the Middle East. In Water, Energy \& Food Sustainability in the Middle East (pp. 389440). Springer, Cham.

- TravelHealthPro (2019). E. Coli Advice for Travellers To Egypt. Retrieved from: https://travelhealthpro.org.uk/news/444/ecoliadvice-for-travellers-to-egypt.

- U.S Food and Drug Administration (2019). Escherichia coli (E. coli). Retrieved from: https://www.fda.gov/food/foodbornepathogens/ escherichia -coli-e-coli.

- U.S. \& Foreign Commercial Service and Department of State (2010). Doing Business in Egypt: 2015 Country Commercial Guide for U.S. Companies. Retrieved from: https://photos.state.g ov/libraries/egypt/5/business/2015EgyptCCG. pdf.

- Wilcock, A., Pun, M., Khanona, J., \& Aung, M. (2004). Consumer attitudes, knowledge and behaviour: a review of food safety issues. Trends in Food Science \& Technology, 15(2), 56-66.

- Winstead, A., \& Hunter, J., and Griffin, p. (2019) . Travel-Related Infectious Diseases: Escherichia coli, Diarrheagenic, National Center for Emerging and Zoonotic Infectious Diseases (NCEZID). Division of Global Migration and Quar antine (DGMQ). Retrieved from:https://wwwnc.cdc.gov/travel/yellowboo k/2020/travel-related-infectious-diseases / escherichia - coli-diarrheagenic.

- World Health Organization (2009). 10 facts on food safety. Retrieved from: http://www.who.int/features/factfiles/food_saf ety/en/.

- World Health Organization. (2000). Foodborne disease: a focus for health education. World Health Organization. 
- World Travel and Tourism Council (2007). Progress and Priorities 2006-07. Retrieved from: www.wttc.travel/b

- Yashoda, K. P., Sachindra, N. M., Sakhare, P. Z., \& RAO, D. N. (2001). Microbiological quality of broiler chicken carcasses processed hygienically in a small scale poultry processing unit. Journal of food quality, 24(3), 249-259.

- Yeung, R. (2009). Tourist perception of food safety risk and destination choice. International Journal of Hospitality and Tourism Systems, 2(1), 21. 